\title{
Nostalgia and Archival Footage in Contemporary Hungarian Documentary (Gábor Zsigmond Papp: The Life of an Agent)
}

Images vol. XV/no. 24 Poznań 2014 ISSN 1731-450X

Archival and found footage have played an important role in Hungarian cinema since the 1960s. This type of material has been present not only in documentaries but also in Hungarian feature and experimental films. After providing a very short summary of the history of the usage of archival footage in Hungarian cinema, I will discuss two contemporary trends in documentaries: the artistic/experimental use and the entertaining/nostalgic use of found footage. At the end of my article, I will use Gábor Zsigmond Papp's documentary film The Life of an Agent as an example of the nostalgic use of archival material in the representation of a still unresolved Hungarian historical problem: socialist secret agents.

From the beginning of the 1960 , it was common to use archival footage in Hungarian feature films in order to evoke an earlier time period and provide historical context for a film's story.[1] The most common strategy was (and still is) placing archival footage in the exposition of the film and using it to establish the diegetic world of the story.[2] As Dezső Magyar, one of the leading Hungarian experimental filmmakers in the 1970s, once said: archival material is the "poor filmmaker's flashback".[3]

Many of these feature films refer to the history of the 1956 uprising and use archival footage that was shot during it.[4] These archival pictures maintained their provocative power up till the end of the socialist era. The political consensus the Kádár regime was built upon (after the revolution was violently suppressed with the help of Soviet troops) was based on a lie about 1956: the unfortunate events had to be treated publicly as a counter-revolution organized and led by the internal enemies of the Hungarian people. However, archival pictures from the days of the uprising have kept their provocative meaning, visually preserving a piece of truth that can be viewed as evidence contradicting the regime's lies about 1956.

[1] Several important examples: Father (István Szabó, 1966), Budapest Tales (István Szabó, 1977), Time Stands Still (Péter Gothár, 1982), The Disciples (Géza Bereményi, 1985), Whooping Cough (Péter Gárdos, 1987), The Midas Touch (Géza Bereményi, 1988), Utrius (Ferenc Grunwalsky, 1993), Bolshe Vita (Ibolya Fekete, 1995), Taking Sides (István Szabó, 2001), The Unburied Man (Márta Mészáros, 2004).

[2] For an excellent summary of the different uses of archival and found footage in Hungarian cinema see: K. Muhi, "A talált képek vonzásában. Archívok a magyar filmben" [Under the Spell of Found Images. Archival pictures in Hungarian Cinema], Metropolis 1997, Summer, pp. 76-91.

[3] Ibidem, p. 76.

[4] Most prominent examples are: Father, Time Stands Still, Whooping Cough, The Midas Touch. 


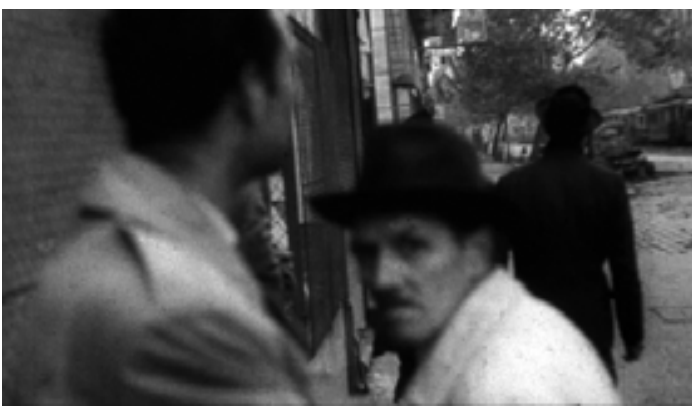

Time Stands Still, dir. Péter Gothár, 1982

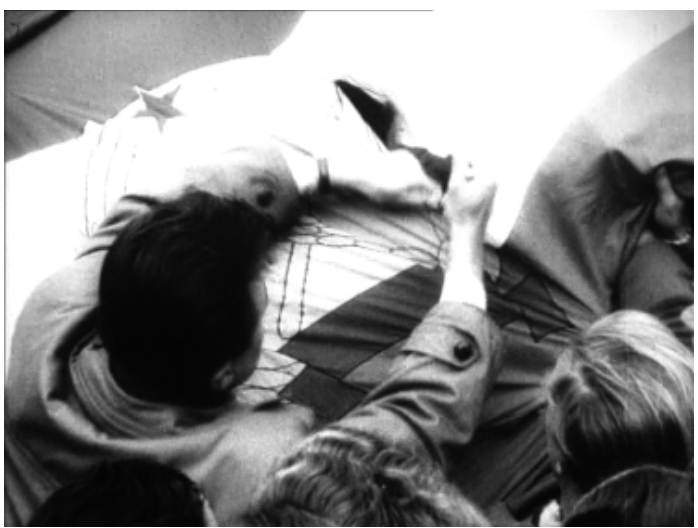

The Midas Touch, dir. Géza

Bereményi, 1988

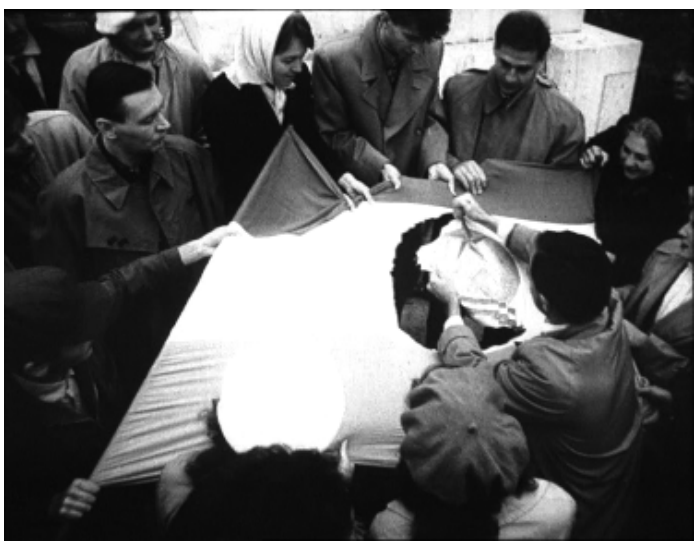

The Midas Touch, dir. Géza

Bereményi, 1988

[5] K. Muhi, op. cit., p. 76.

[6] About the use of archival material in the films of BBS see: A. Murai, "Emlék-nyom-követés. Az archív felvételek stílusalakzatai” [Memory-Trace-Pur-
This is why it is so striking when someone from these blurred pictures glances into the camera as happened at the beginning of the 1982 film Time Stands Still (directed by Péter Gothár). "That glance contains the shocking civilian gesture that is impossible to be played by an actor, and there is also the unique configuration of man, history and camera." [5] This unique configuration has even more significance when the man in the picture who looks into our eyes is a victim of an unquestionable, consensual lie the audience also lives in - as was the case with Hungarians at the time of the premier of Gothár's film.

Feature films find many ways to use archival material creatively. One of the creative methods can be seen in The Midas Touch, where the director mixes together archival footage and his own pictures. There are two scenes showing the cutting out of the communist symbol from the Hungarian flag - the second is shot by the filmmakers, while the first one is actually a "fake" archival picture created somewhere outside of Hungary for propagandistic purposes during the revolution. The strategy of mixing found footage and pictures shot for fiction film helps the filmmaker to use the authenticity provided by documentary images to validate the diegetic word of his fiction. However, in the case of The Midas Touch the use of fake documentary material complicates the situation and can be read as a commentary on the very strategy the film uses.

In Hungary, serious artistic experimentation with archival and found footage started in the 1970 and was carried out by young directors from the Béla Balázs Studió (BBS).[6] Meanwhile, feature films mainly used archival footage in order to authenticate a film, to help the viewer settle into the world of the story; the BBS experiments intended to reveal the constructed nature of the world and truth by

suit. Stylistic Formations of Archival Footage], in: BBS 5o. A Balázs Béla Stúdió 50 éve, ed. G. Gelencsér, Budapest, Mücsarnok - Balázs Béla Stúdió, 2009, pp. 115-127. 
using archival pictures. As Dezső Magyar, the director of two significant experimental films of the era (The Agitators, 1970; Punitive Expedition, 1971), has said:

The archival footage is the moment of unquestionable truth. When edited into the material we had created it reveals every kind of lies, fake acting and posing, and unreasonable behaviour in a way that almost puts us to shame. ${ }^{7}$

The most talented filmmakers of the 1970 s all believed in archival footage, whether it be real found footage or imitated archival material. They thought this type of picture provided a better chance than any feature film to investigate the real meaning of past and present events in a political era that was built on a lie.

Their trust and interest in archival pictures led to many interesting aesthetic experiments. Gábor Bódy created the film American Torso in 1975 by imitating found footage. The film was shot as if an amateur cameraman had been present in the American civil war in the 1860 s in North Carolina. The viewer has the feeling that what can be seen on the screen is actually found footage from a time period when the film camera did not yet exist. Bódy created two gazes:[8] the first, the "original" gaze of a fictional cameraman from the 19th century who was present in North Carolina and witnessed and recorded historical events, and a secondary, analytical gaze of the actual filmmaker of the film American Torso.

Another exciting trend was to treat found footage as a fossil, an artefact, that had to be polished; the layers covering the real meaning of the pictures need to be removed to reveal the truth buried in them. [9] A significant experiment from this trend is the film Private History by Gábor Bódy and Péter Tímár from 1978. They used amateur, private family movies from the 1930 s and 1940 s and used different methods to manipulate, remix and reframe the original pictures in order to create a "historical collage", a playful montage of collective memory. They called their strategy framing or reframing, describing where a filmmakers' work with material (editing, mixing visual with sound, altering the speed of images) helps to bring forward a potential truth hidden inside these types of pictures.

Probably one of the internationally most renowned directors utilising this strategy today is Péter Forgács, who uses privately produced material from many sources and historical periods, and reinterprets important historical events from a very unique, private point of view.[10] He started the series Private Hungary back in 1988, and has created more than a dozen episodes since. The first part of his series is actually based on the same material as those present in Private History by

[7] K. Muhi, op. cit., p. 77.

[8] Ibidem, p. 85.

[9] Ibidem, pp. 86-88.

[10] About his work see: Cinema's Alchemist: The

Films of Peter Forgacs, eds. B. Nichols, M. Renov, Vis- ible Evidence series, no. 25, University of Minnesota Press, 2011. In Hungarian a collection of essays about his work has been published in the quarterly film theory journal Metropolis (Summer 1999). 
Bódy and Tímar. However, Forgács has created a completely different interpretation, a more "private" perspective by using different aesthetic strategies when remixing the original pictures.

Forgács's films often envision the grand stories of unresolved collective traumas, stories about the Holocaust, forced migration, the Spanish civil war. He always concentrates on people: telling stories of everyday people who was caught in the midst of history. The private point of view that is being revealed in his films with the help of found footage urges the viewer to reinvent collective memory as a collection of private feelings and emotions, private stories of suffering and happiness. Forgács is most interested in revealing the hidden truth buried under unresolved historical traumas. His work is a prototype of the artistic/ experimental use of found footage: he digs deep and is ready to make his viewer suffer by evoking deep personal sympathy towards real individuals who suffered in the past in order to heal the pain caused by historical traumas.

A less painful way to face past events is by remembering only non-traumatic episodes. This strategy is used by the so-called retro documentaries, which I am going to call the "entertaining/nostalgic trend". One of the most prominent followers of this trend in Hungary is Gábor Zsigmond Papp and his "retro series". This series consists of films that concentrate on the nostalgic quality associated with archival material.[11] Papp uses archival educational and commercial propaganda films to evoke the everyday life of Hungarians during the Kádár era. He does not alter the material significantly, but merely creates thematic groups or chapters in the films by collecting excerpts from different sources that represent the same cultural, political or economical issues

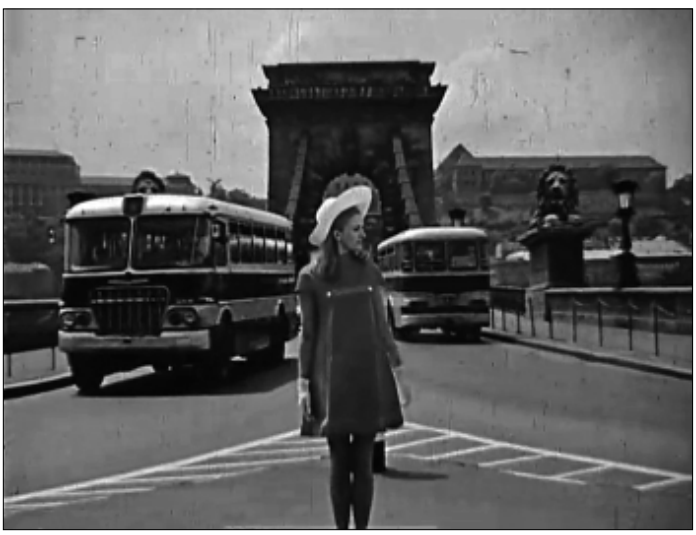

(shopping, fashion, holidays, the Hungarian worker, farmer, etc.).

It is easy to guess how much the life presented in these commercial propaganda films has to do with the everyday life of Hungarians of those days. Yet still, while watching these colourful happy images, the viewer tends to believe that since Hungarian women were beautiful even in socialist times, it must have made it easier to survive the 1960 s and 1970 .

The nostalgic tone suggests an unproblematic relationship to and a longing for the past. The non-problematizing angle makes it

4. Budapest Retro, vol. 2, dir. Gábor Zsigmond Papp, 2003 possible to use the original material untouched, without any stylistic commentary. However, it seems that highly problematic historical questions need a more reflexive treatment even if they appear as part of this nostalgic trend.

[11] The films are the following: Budapest Retro 1-2 (2002, 2003), Balaton Retro (2007), Hungarian Retro (2010). 
The issue of socialist secret agents and informers is still a skeleton locked in the cupboard in Hungary. Although this skeleton makes incredible noise, shaking its bones inside that cupboard, politicians and the academia do not seem to be ready to start public discussion about the topic. This is why it is quite significant that in the last few years young filmmakers, born after the heyday of socialist informers, seem to be interested in the topic and ready to shed light on this dark corner of our recent past.[12]

At the opposite end of the continuum of East European political strategies after the fall of communism there have been two different approaches: "prosecute and punish" on the one side, and "forgive and forget" on the other. The "prosecute and punish" strategy is represented by East Germany, while "forgive and forget" can be associated with Poland. "On the continuum of East European transitional justice strategies, Czechoslovakia sits with East Germany nearer the 'prosecute and punish' than the 'forgive and forget' pole," [13] while Hungary seems to be nearer to Poland where reconciliation with communist crimes were postponed and left unresolved. As Ewa Mazierska argues in her book European Cinema and Intertextuality: History, Memory and Politics in the chapter devoted to the question of communist secret agents in German, Polish and Czech films: "The countries in which the secret files feature most prominently in national cinemas, Germany and Poland, are those which initially adopted opposite approaches to their communist past." [14] It seems that Hungary has recently started to move closer to Poland by producing more and more films about the issue of secret agents.

So-called "lustration" is the process of screening people to check whether they were agents, informers or collaborators during communist times. Although in countries like Poland and Hungary these screenings were very limited, affecting only top public servants, prosecutors, judges and journalists. In Hungary, the "lustration" or "agent" law went into effect in 1994, but because many of the files were qualified as top secret, even lustration was ineffective. Since all political sides present in parliament were (and still are) against full clarification of the matter, the parliament constantly declines to settle this issue and fully open the secret files. (During the campaign of the last parliamentary election in 2014, this was an issue again: politicians of the opposition stated that they are ready to fully open the files in case of their victory. The oppo-

[12] Important film examples that have been dealing with the agent/informer topic recently: Apaches (filmfor TV, directed by Ferenc Török, 2010), The Exam (thriller, directed by Péter Bergendy, 2010), Dear Betrayed Friends (drama, directed by Sára Cserhalmi, 2012).

[13] N. Nedelsky, "Czechoslovakia and the Czech and Slovak Republics," in: Transitional Justice in Eastern
Europe and the Former Soviet Union: Reckoning with the Communist Past, ed. L. Stan, London, Routledge, 2009, pp. 37-75; op. cit. p. 37 - quoted in: E. Mazierska, European Cinema and Intertextuality: History, Memory and Politics, Palgrave Macmillan, New York 2011, p. 237.

[14] E. Mazierska, op. cit., p. 209. 
sition has been defeated.) Given these circumstances, the treatment of the topic in art has even more significance in Hungary.

Academic discussions in past decades about history and remembering, the work of memory, the concepts of collective, cultural and public memory - represented by the works of Pierre Nora, Andreas Huyssen and Hayden White - have gained prominence.[15] These authors argued very convincingly that the process of collective remembering is of the utmost importance to any modern society for the purpose of establishing and maintaining identity. In this process, film plays a crucial role as an art form and as popular entertainment, as well. Also important is that since history does not exist as an objective story out there somewhere, remembering is always a process of creation and recreation, and the creative processes expressed in films as narrative discourses are the layers that create the sense of the phenomenon we call history. I believe it is important to recognize the structures of remembering, but also its limits. In artworks, especially in narrative discourses, it is important to reflect on the means of remembering, the complexity of the process, and the limits of representation.

What interests me most is the form of discourse a film uses when recalling the history of communist secret agents. In his film The Life of an Agent, Gábor Zsigmond Papp uses archival material and several creative strategies in order to discuss and reconstruct the highly controversial topic of socialist secret agents in Hungary. The material he uses has a unique history itself.

There was a secret film studio in Budapest that belonged to the Interior Ministry. It produced 300 tutorial movies during its 30 years of existence. Most of the films were educational films for ordinary policemen. However, the studio was secret because of the movies it produced to train state security professionals: surveillance technicians, agents and contact officers. These Top Secret films were only seen by students of the police academy - even the projectionist had to leave his booth during projection. These movies showed how to raid homes, and demonstrated surveillance techniques and procedures for recruiting new agents.

Gábor Zsigmond Papp's documentary collects the most interesting excerpts from these once-secret educational films and presents to the viewer the profane and surreal word of communist agents. Arranged in three chapters, the film concentrates on the topic of surveillance, house-searches, and the enlistment of new informers.

From the original excerpts, we learn, for example, what a secret surveillance handbag looks like and the many useful features it has. In

[15] See for example: P. Nora, Between Memory and History: Les Lieux de Mémoire (trans. Marc Roudebush), Representations (1989), no. 26, pp. 7-25; idem, Realms of Memory: Rethinking the French Past (trans. A. Goldhammer), Columbia University Press, New
York 1996-1998; A. Huyssen, Present Pasts: Urban Palimpsests and the Politics of Memory, Stanford University Press, 2003; H. White, The Content of the Form: Narrative Discourse and Historical Representation, Johns Hopkins University Press, Baltimore 1987. 
these episodes, when the important tools of the agents' work are presented we hear a voice over that is part of the original footage. These intriguing and, at the same time, entertaining pictures show funny and - for contemporary audiences - childish looking, primitive equipment. It is almost impossible to imagine that the agents of the secret service were able to destroy people's lives by using these tools. The quality that most easily could be associated with these innocent looking pictures is nostalgia. They might even help us to forget about the dark side of the history hiding behind them.

The film also uses its own voice-over commentary to connect archival pictures with texts originating from the socialist era. In these cases, the director combines footage from original educational films and mixes them with a voice-over quoting from official documents of the time. For example, we see a scene from an educational film where a house and body search are demonstrated; meanwhile, the narrator of the film reads the State Security Regulation issued in 1972 about the tariffs for conducting these activities. These scenes stress the surreal quality of the actions and facts presented.

The film also contains footage shot by the filmmakers. In these scenes, the characters imitate surveillance: a group of people, whom we do not see, but only hear their voices, follow and record the everyday doings of a man. These "fictional" scenes are enactments of the tasks presented by the archival educational films, but, at the same time, they can be seen as a mockery of the agents' activities. For example, there are scenes where we witness how inappropriate the knowledge the invisible, fictional agents have about such basic tasks as surveillance and collecting evidence.

By mixing archival footage from the educational films, voiceovers quoting official documents from the era, and "fictional" surveillance footage shot by the film makers as if the they were conducting a secret operation themselves, the film intends to build a layered discourse and demonstrate the problematic connection between archive footage, documents, and fiction. (We also learn that some of the educational films themselves were narratives featuring prominent Hungarian actors.)

Documentary and fictional aspects seems to be entangled, not only in the educational material, but in Gábor Zsigmond Papp's documentary itself, as well. The film ends with a voice over commentary reflecting on what the audience had just seen:

This film has been two years in the making. We had two years to interpret the thoughts, fears and deeds of those, who took part in the making of this tragic, sometimes comic, but most of all, surreal world. Characters of this world

5. The Life of an Agent, dir. Gábor Zsigmond Papp, 2004 
invented their own language. People have plots instead of stories, messages are transmitted through object post-boxes. Phone tapping is a numbered regulation, tale-telling is network activity. The leather-coated men of this world dissemble armchairs diligently searching for a pornographic picture or a 100-dollar note. This canvas was populated by agents, inceptors and counter-interceptors, investigators and keepers, who meet in conspiracy apartments to write reports for themselves. The films quoted here had no directors and no actors. Even staff lists are missing. So we might as well think that the things we have just seen has never really happened.

On the whole, play with the problematic relation between document and fiction is a reflection of the situation of the still-obscure word of socialist secret files, and at the same time, creates entertainment value. The film is both a thrilling story about the secret life of communist agents illustrated by miniature episodes of conspiracy, as well as an almost unbelievably funny and surreal farce with tariffs of body searching, episodes of coffee drinking, and bacon eating surveillance operators who are acting out the "real life" of Secret Police officers. Historical education and quality entertainment in one film.

To sum up the features of the work of memory present in the above-mentioned Hungarian documentaries, both the use of found footage and the recreation of private lives and feelings in Forgács's experimental films help the audience face painful memories related to Hungary's collective history. In addition, the nostalgic use of archival material that was originally produced by official bodies of the socialist system make us laugh at the absurdity of the socialist regime, but do not force the viewer to face the horrible consequences that that absurd system had for the lives of its victims.

Cry and remember - Péter Forgács tells us; laugh and forget about it - suggests Gábor Zsigmond Papp. 